\title{
Seasonal speed-up of two outlet glaciers of Austfonna, Svalbard, inferred from continuous GPS measurements
}

\author{
T. Dunse ${ }^{1}$, T. V. Schuler ${ }^{1}$, J. O. Hagen ${ }^{1}$, and C. H. Reijmer ${ }^{2}$ \\ ${ }^{1}$ Department of Geosciences, University of Oslo, P.O. Box 1047, Blindern, 0316 Oslo, Norway \\ ${ }^{2}$ Institute for Marine and Atmospheric Research Utrecht, Utrecht University, Princetonplein 5, 3584 CC Utrecht, \\ The Netherlands
}

Correspondence to: T. Dunse (thorben.dunse@geo.uio.no)

Received: 2 November 2011 - Published in The Cryosphere Discuss.: 8 December 2011

Revised: 1 March 2012 - Accepted: 19 March 2012 - Published: 10 April 2012

\begin{abstract}
A large part of the ice discharge from ice caps and ice sheets occurs through spatially limited flow units that may operate in a mode of steady flow or cyclic surge behaviour. Changes in the dynamics of distinct flow units play a key role in the mass balance of Austfonna, the largest ice cap on Svalbard. The recent net mass loss of Austfonna was dominated by calving from marine terminating outlet glaciers. Previous ice-surface velocity maps of the ice cap were derived by satellite radar interferometry (InSAR) and rely on data acquired in the mid-1990s with limited information concerning the temporal variability. Here, we present continuous Global Positioning System (GPS) observations along the central flowlines of two fast flowing outlet glaciers over 2008-2010. The data show prominent summer speedups with ice-surface velocities as high as $240 \%$ of the presummer mean. Acceleration follows the onset of the summer melt period, indicating enhanced basal motion due to input of surface meltwater into the subglacial drainage system. In 2008, multiple velocity peaks coincide with successive melt periods. In 2009, the major melt was of higher amplitude than in 2008. Flow velocities appear unaffected by subsequent melt periods, suggesting a transition towards a hydraulically more efficient drainage system. The observed annual mean velocities of Duvebreen and Basin-3 exceed those from the mid-1990s by factors two and four, respectively, implying increased ice discharge at the calving front. Measured summer velocities up to $2 \mathrm{~m} \mathrm{~d}^{-1}$ for Basin-3 are close to those of Kronebreen, often referred to as the fastest glacier on Svalbard.
\end{abstract}

\section{Introduction}

Spatially limited fast-flow units are a typical feature of large ice caps and ice sheets and responsible for most of the ice flux from the interior/accumulation area towards the margin/ablation area. Changes in the dynamics of these flow units have important implications for glacier mass balance. Transported towards the margin, ice is exposed to increased surface melt and, in case of marine-terminating outlets, iceberg calving. The calving rate depends on the ice flux towards the calving front and the change in position of the terminus. Iceberg calving allows for more rapid and abrupt ice mass loss than surface melt. Its potential contribution to eustatic sea-level rise (SLR) is suggested to account for up to $2 \mathrm{~m}$ by the end of this century (Pfeffer et al., 2008). Yet, this contribution is excluded from the last consensus estimate, 0.18-0.6 m SLR until 2100, by the Intergovernmental Panel on Climate Change (IPCC) Fourth Assessment (Solomon et al., 2007).

Fast glacier flow is generally achieved by basal motion rather than by internal deformation and requires basal temperatures at or near the pressure-melting point. In the presence of a basal layer of soft ice, e.g. temperate ice of iceage origin, enhanced deformation of this layer may considerably contribute to glacier flow (Lüthi et al., 2002). Basal motion refers to sliding of the ice base over bedrock (Clarke, 1987) or deformation of subglacial sediments (Clarke et al., 1984; Tulaczyk et al., 2000; Fischer and Clarke, 2001). On shorter timescales (hourly to seasonal), flow variations appear closely linked to changes in effective pressure at the glacier base, i.e. ice overburden reduced by basal water pressure (Meier and Post, 1987). For tidewater glaciers, speed-up may also be driven by the reduction of back-stress at their 

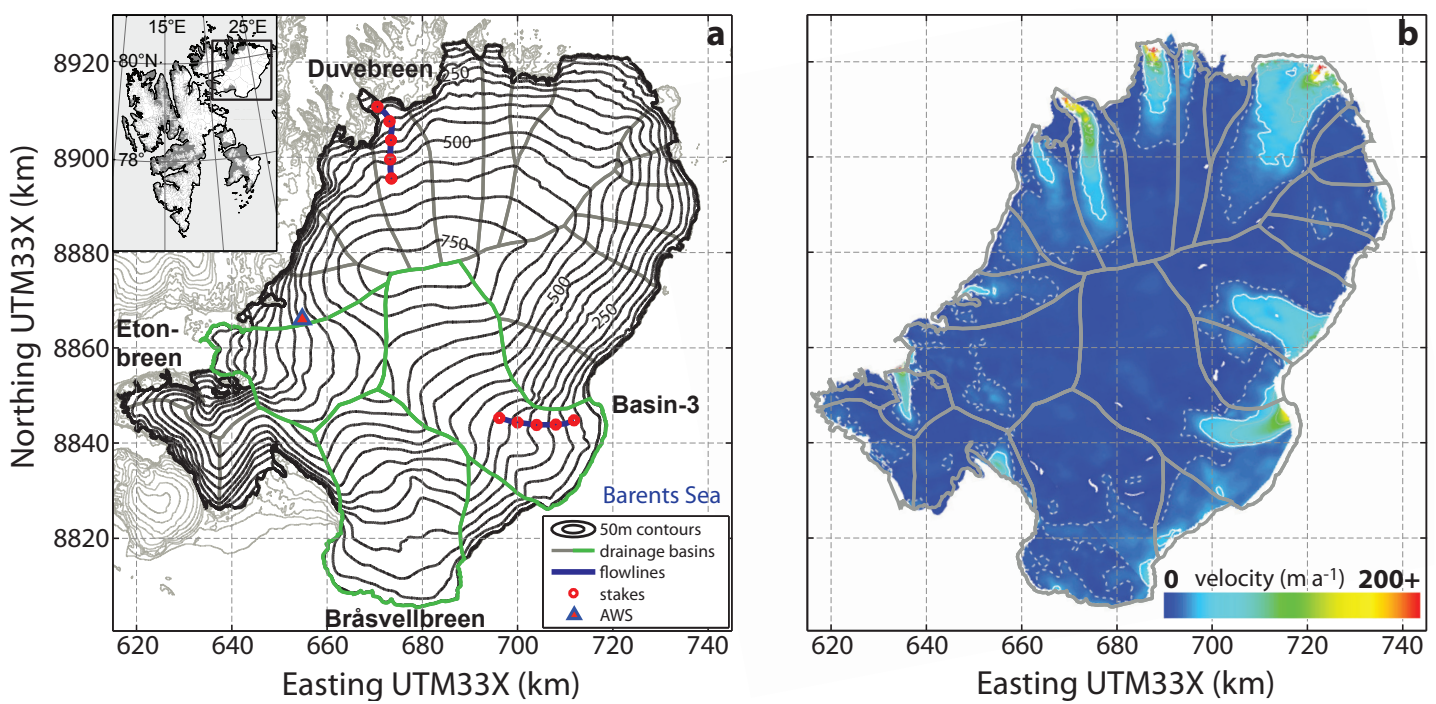

Fig. 1. Topographic and dynamic characteristics of Austfonna. (a) Surface topography of Austfonna with 50 m elevation contours according to a new DEM by Moholdt and Kääb (2012). The black rectangle in the inset indicates the location within the Svalbard archipelago. Drainage basins are outlined in solid grey, in the case of the known surge-type basins in solid green. The survey routes along the central flowlines of Duvebreen and Basin-3 are marked in solid blue, the position of stakes with red dots and the AWS on Etonbreen with a triangle. (b) Surface velocity structure of Austfonna derived from ERS-1/2 SAR scenes acquired between December 1995 and January 1996. Dashed contours indicate a velocity of $10 \mathrm{~m} \mathrm{a}^{-1}$, solid contours are at $25 \mathrm{~m} \mathrm{a}^{-1}$ intervals. Modified from Dowdeswell et al., Iceberg calving flux and mass balance of the Austfonna ice cap on Nordaustlandet, Svalbard, J. Geophys. Res., 113, F03022, 2008. (02008 American Geophysical Union, by permission of the American Geophysical Union.

termini (Joughin et al., 2008; Nick et al., 2009), such as caused by calving events (Thomas, 2004) or buoyancy perturbations due to ocean tides (O'Neel et al., 2003). Velocity fluctuations may propagate up-glacier by means of longitudinal stress coupling (Price et al., 2008).

Excessive input of meltwater into the subglacial drainage system early in the summer melt season increases the basal water pressure, thereby weakening the ice-bed coupling and promoting high velocities in excess of those during winter (Iken and Bindschadler, 1986). While the phenomenon was first observed and studied on alpine glaciers, enhanced icesurface velocities following surface melt were also reported for the Greenland ice sheet (Zwally et al., 2002; Joughin et al., 2008; Andersen et al., 2010; Bartholomew et al., 2010; Sole et al., 2011) and polythermal Arctic glaciers (Copland et al., 2003; Nuttall and Hodgkins, 2005; Rippin et al., 2005). In polar environments, glacier acceleration usually lags the onset of summer melt. Meltwater refreezes in the snowpack until the cold-content of the snow (and firn) is diminished, thereby causing delayed runoff. Basal lubrication does not occur before a connection between the supraglacial and englacial/subglacial drainage system is established (Copland et al., 2003). Abrupt and vigorous water input may follow drainage events of supraglacial lakes, that are known to form at the surface of many Arctic glaciers during summer.

The relationship between surface melt and glacier acceleration is not linear, but depends on the nature of the basal hydraulic system and the response time needed to adjust for changes in water input. Sustained input of large volumes of meltwater may retard rather than enhance glacier motion, as recently observed in SW Greenland (van de Wal et al., 2008; Bartholomew et al., 2011b; Sundal et al., 2011). Model results illustrate that a transition from a hydraulically inefficient distributed drainage system to an efficient channelized system can explain glacier slow-down during sustained melt periods (Schoof, 2010).

Ice-surface velocity maps of good spatial resolution can be derived from satellite radar interferometry (InSAR; e.g. Rott, 2009) or speckle/intensity tracking of SAR intensity images (Strozzi et al., 2002). A disadvantage of these methods is that suitable data is only available for limited time periods. Continuous or repeated ground-based Global Positioning System (GPS) observations yield displacement rates of specific surface points. GPS measurements provide velocity time series at the desired temporal resolution and at high accuracy, however, with limited information on the spatial variability.

At Austfonna, the largest ice cap on Svalbard (Fig. 1a), InSAR revealed distinct fast-flow units embedded in a slow moving bulk of the ice cap (Fig. 1b; Dowdeswell et al., 1999; Bevan et al., 2007). These studies rely on data acquired during the winter months of the mid 1990s. They do not capture the seasonal variability and may not reflect the present dynamics of individual outlet glaciers. The ice cap comprises several surge-type basins and its current 
net mass loss is mainly attributed to calving from the marine ice margin (Dowdeswell et al., 2008; Moholdt et al., 2010). A previously published calving estimate of $2.5 \pm$ $0.5 \mathrm{Gt} \mathrm{a}^{-1}$ (Dowdeswell et al., 2008) relies on the mid 1990s surface-velocity snapshots.

In this study, we present continuous GPS measurements along the central flowlines of Duvebreen and Basin-3, two of Austfonna's fast-flow units. The GPS records span a twoyear period, and allow investigation of seasonal and yearto-year changes in flow velocities. Basin-3 was reported to have undergone a short-lived flow-instability or "mini-surge" in the early 1990s (Dowdeswell et al., 1999). In parallel with the GPS data, we consider the temperature record of a nearby automatic weather station to investigate a possible relationship between surface melt and flow dynamics. We also compare the recently measured flow velocities with those from the mid 1990s.

\section{Survey area}

\subsection{The Austfonna ice cap}

Austfonna is a $7800 \mathrm{~km}^{2}$ ice cap (Moholdt and Kääb, 2012) centered at $79.7^{\circ} \mathrm{N}, 24.0^{\circ} \mathrm{E}$ on the island Nordaustlandet, in the northeast of Svalbard (Fig. 1a). The ice cap represents the largest ice body on the highly glacierized archipelago. It consists of one main dome that rises to $800 \mathrm{~m}$ a.s.l., where the ice thickness reaches its maximum of about $580 \mathrm{~m}$ (Dowdeswell et al., 1986). A main ice divide separates the northwestern basins, predominantly terminating on land or in narrow fjords, from the southeastern basins, that are to a large extent grounded below sea level and form an almost continuous calving front towards the Barents Sea (Dowdeswell, 1986; Hagen et al., 1993). InSAR data acquired in the winter months of the mid 1990's revealed that a large portion of the ice cap is moving at low velocities $<10 \mathrm{~m} \mathrm{a}^{-1}$, interrupted by spatially limited flow units characterized by ice surface velocities in the range of about $50-250 \mathrm{~m} \mathrm{a}^{-1}$ (Dowdeswell et al., 1999, 2008; Bevan et al., 2007, Fig. 1b). The location of these flow units coincides with subglacial valleys or troughs. This velocity pattern appears to be typical for many Arctic ice caps, e.g. the Devon Island Ice Cap in Arctic Canada (Dowdeswell et al., 2004) or the Academy of Sciences Ice Cap in the Russian Arctic (Dowdeswell et al., 2002). Model results suggest that the large ice thickness within these valleys allows for temperate basal conditions, and hence, basal motion as the dominant mechanism of ice flow (Dunse et al., 2011). Several basins are known to have surged in the past; Etonbreen and Bråsvellbreen in the 1930s and Basin-3 around 1850-1870 (Schytt, 1969; Lefauconnier and Hagen, 1991). A submarine push-moraine in front of Basin-5, a northeastern neighbour of Basin-3, also suggests that this basin may have surged, probably within the past 100 years (Robinson and Dowdeswell, 2011). Currently ob- served elevation changes display interior thickening at rates of up to $0.5 \mathrm{~m} \mathrm{a}^{-1}$ and marginal thinning at $1-3 \mathrm{~m} \mathrm{a}^{-1}$ (Bamber et al., 2004; Moholdt et al., 2010) and can be explained by low ice flux rates within surge-type basins in their quiescent phase (Hagen et al., 2005; Bevan et al., 2007). Bamber et al. (2004) suggested increased moisture flux from the adjacent Barents Sea, and hence increased accumulation, as the cause for the positive elevation changes in the accumulation area. However, this hypothesis is not supported by accumulation measurements using shallow ice cores, indicating unchanged long-term net accumulation rates over the time periods 1963-1986 and 1986-1998, respectively (Pinglot et al., 2001). In-situ mass balance measurements over the time period 2004-2008 indicate a surface mass balance close to zero (Moholdt et al., 2010). The mean equilibriumline altitude (ELA) equaled about $450 \mathrm{~m}$ a.s.l. for the northwestern and $300 \mathrm{~m}$ a.s.1. for the southeastern basins. In 2008, the ELA was significantly lower. Yet, the net mass balance of Austfonna over the period 2002-2008 was negative, $-1.3 \pm 0.5 \mathrm{Gt} \mathrm{a}^{-1}$ (Moholdt et al., 2010), due to calving and retreat of the marine ice margin at rates of several tens of meters per year during the past few decades (Dowdeswell et al., 2008).

Here, we focus on the central flowlines of two fast-flowing outlet glaciers along which surface velocities were determined earlier by Dowdeswell et al. (1999): Duvebreen in the northwestern and Basin-3 in the southeastern section of the ice cap (Fig. 1a). When the flowlines were visited on $25 \mathrm{Au}-$ gust 2008, a continuous winter snow cover persisted down to the calving termini. In 2009 the ELA was positioned higher up than in 2008, but still below average, at about $200 \mathrm{~m}$ a.s.l. on both Duvebreen and Basin-3. In the following, we present general features of the dynamics of the two basins and the geometries along their central flowlines. The latter is based on ground-penetrating radar (GPR) and kinematic GPS data, further described in Sect. 3.2 and Appendix A. Each flowline is defined by five specific survey locations, equidistantly distributed over a length of $16 \mathrm{~km}$ (Fig. 2).

\subsection{Basin-3}

Basin-3 coincides with the eastern half of a major valley that runs west-eastwards across Nordaustlandet. A large area of the basin is marine grounded to a maximum depth of $\sim 150 \mathrm{~m}$ below sea level and the terminus calves into the Barents Sea (Dowdeswell, 1986). Here, we discuss observations along a $16 \mathrm{~km}$ long section of the flowline (Figs. 1a and 2a). Surface elevations range from $121 \mathrm{~m}$ a.s.l. at the lower end, $\sim 5 \mathrm{~km}$ from the calving front, to $356 \mathrm{~m}$ a.s.l. at the upper end (Table 1), with a mean surface slope of $0.84^{\circ}$. The glacier is grounded below sea level along the entire section. The bedrock is relatively flat over the lower $12 \mathrm{~km}$ of the profile, with bedrock elevations around $-100 \mathrm{~m}$ a.s.l. Farther upstream, the bedrock rises to near sea level and features 
Table 1. Survey locations of stakes along the central flowlines of Basin-3 (B3 \#1-5) and Duvebreen (Duve \#1-5) and their glacier-geometric characteristics. Positions are measured directly and the associated absolute error given in the last row is constant. Ice thickness and hence, bedrock elevation are indirectly measured, the associated error is ice-thickness depended. Values marked by ${ }^{*}$ are interpolated values (see Sect. A).

\begin{tabular}{|c|c|c|c|c|c|}
\hline $\begin{array}{l}\text { Stake } \\
\text { (no.) }\end{array}$ & $\begin{array}{c}\text { Latitude } \\
\left(\text { decim. }^{\circ} \mathrm{N}\right)\end{array}$ & $\begin{array}{l}\text { Longitude } \\
\left(\text { decim }^{\circ} \mathrm{E}\right)\end{array}$ & $\begin{array}{l}\text { Surface alt. } \\
\text { (m a.s.1.) }\end{array}$ & $\begin{array}{l}\text { Ice thickness } \\
\text { (m a.s.l.) }\end{array}$ & $\begin{array}{c}\text { Bedrock elev. } \\
\text { (m) }\end{array}$ \\
\hline B3 \#1 & 79.4992370 & 25.468043 & 121.2 & $220^{*}$ & $-99 *$ \\
\hline B3 \#2 & 79.4976114 & 25.273292 & 184.2 & $281^{*}$ & $-97^{*}$ \\
\hline B3 \#3 & 79.5032166 & 25.077680 & 249.4 & 329 & -80 \\
\hline B3 \#4 & 79.5136708 & 24.889501 & 282.4 & 357 & -75 \\
\hline B3 \#5 & 79.5279278 & 24.710116 & 355.9 & $361^{*}$ & $-5^{*}$ \\
\hline Duve \#1 & 80.1421759 & 23.958117 & 207.1 & 309 & -102 \\
\hline Duve \#2 & 80.1117554 & 24.063358 & 308.4 & 302 & 7 \\
\hline Duve \#3 & 80.0760756 & 24.047865 & 391.4 & 300 & 92 \\
\hline Duve \#4 & 80.0406765 & 24.007224 & 482.1 & 333 & 149 \\
\hline Duve \#5 & 80.0047962 & 23.989474 & 548.4 & 411 & 138 \\
\hline Error & $\pm 0.05 \mathrm{~m}$ & $\pm 0.05 \mathrm{~m}$ & $\pm 0.1 \mathrm{~m}$ & \multicolumn{2}{|c|}{ $\pm 3 \mathrm{~m} *( \pm 14 \mathrm{~m})$} \\
\hline
\end{tabular}
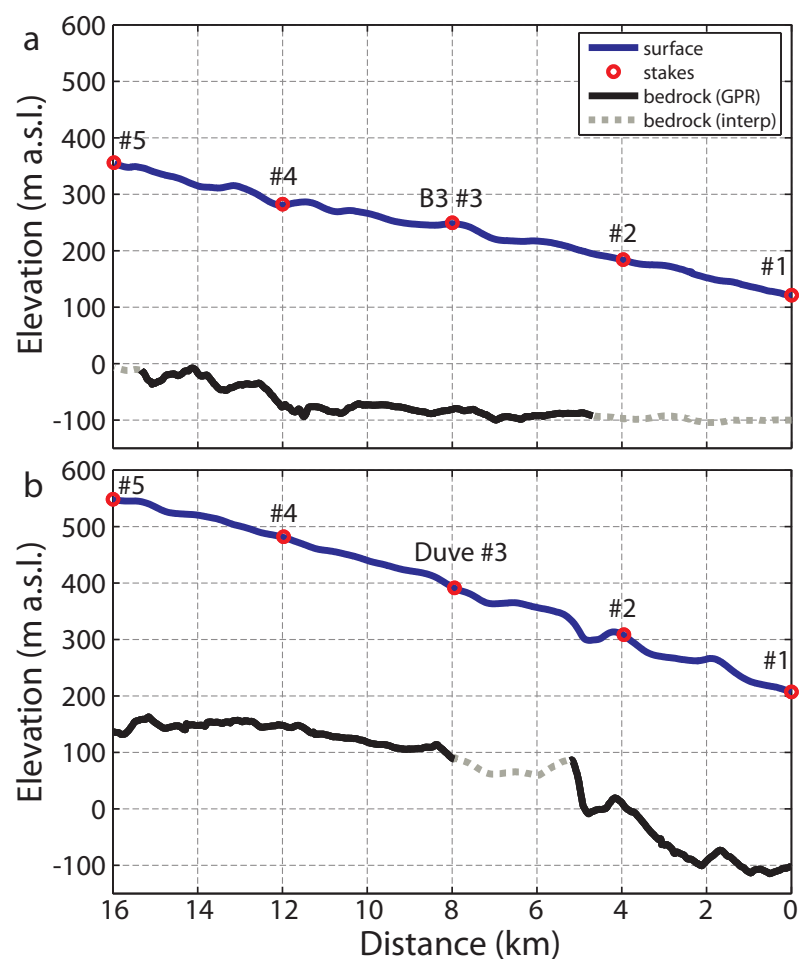

Fig. 2. Glacier geometry along central flowlines of Basin-3 (a) and Duvebreen (b). Surface elevation (solid blue) in $\mathrm{m}$ a.s.l. is based on kinematic GPS measurements, GPR-derived ice thickness subtracted to yield bedrock elevation (solid black and dashed grey). Stake positions are marked with red dots. The lowermost stakes on both flowlines are located $\sim 5 \mathrm{~km}$ upstream from the calving front.

two bedrock protrusions. The ice thickness along the profile gradually thickens upglacier, averaging $313 \mathrm{~m}$.
Basin-3 has surged around 1850-1870 (Lefauconnier and Hagen, 1991), coincident with the Little Ice Age, when many glaciers on Svalbard reached their Holocene maximum extent (Svendsen and Mangerud, 1997). Subsequently, the terminus retreated $\sim 8 \mathrm{~km}$ from its maximum extent marked by the position of a large submarine push moraine (Robinson and Dowdeswell, 2011). The observed surface profile is relatively flat (Dowdeswell, 1986). This may be indicative of the early quiescent phase (Meier and Post, 1969), thus implying a long, multi-century surge cycle. Alternatively, the flat surface profile could be explained by a considerable contribution of basal motion to the overall ice flow.

Application of InSAR to SAR scenes acquired in the early 1990s revealed a distinct flow unit 5-6 km wide and topographically constrained by Isdomen, a prominent subglacial hill to the north (Dowdeswell et al., 1999). Velocities in February 1992 were as high as $140 \mathrm{ma}^{-1}$ at the terminus, whereas in January 1994, only $80 \mathrm{~m} \mathrm{a}^{-1}$ were observed. The absence of significant crevasse fields in Landsat imagery from 1973-1991 suggest that the flow unit was fairly inactive over that time period and fast flow initiated after 1991. Calculated balance velocities were one order of magnitude smaller than the observed surface velocities. Dowdeswell et al. (1999) thus interpreted the change in flow velocities as a short-lived flow instability or mini-surge initiated after 1991, arguing that the ice flux cannot be sustained under the present climate.

\subsection{Duvebreen}

Duvebreen, in the northwest of Austfonna, drains into narrow Duvefjorden where the terminus forms a $\sim 2 \mathrm{~km}$ wide calving front. InSAR-derived velocities for February 1992 
and January 1994 ranged from $20-80 \mathrm{~m} \mathrm{a}^{-1}$ along the central flowline (Dowdeswell et al., 1999).

Surface elevations along the surveyed section range from $207 \mathrm{~m}$ a.s.l., $4-5 \mathrm{~km}$ upglacier from the calving front, to 548 ma.s.l. (Table 1) with a mean surface slope of $1.22^{\circ}$ (Fig. 2b). The ice thickness ranges from $\sim 300 \mathrm{~m}$ to $>400 \mathrm{~m}$ from the lower to upper ends, with a mean of $328 \mathrm{~m}$. The bedrock topography is relatively flat in the upper half, with elevations ranging from 100-160 ma.s.l. Farther downglacier, the bedrock abruptly drops, reaching depths of more than $100 \mathrm{~m}$ below sea level. Bedrock protrusions of several $100 \mathrm{~m}$ in diameter and $20-30 \mathrm{~m}$ heights promote local increase in ice-bed coupling and hence, compressive flow. Convex ice-surface undulations therefore appear slightly upglacier from bedrock protrusions (Gudmundsson, 2003). Vice-versa, concave surface elevations coincide with downglacier sloping bedrock. A very prominent surface depression lies upglacier from the bedrock escarpment. Field inspections in spring 2008 and SPOT-5 satellite imagery from 14 August 2008 (Korona et al., 2009) suggest that a supra-glacial lake forms within the depression during the summer melt season.

\section{Methods}

In spring 2008, we established a series of stakes along the central flowlines of Duvebreen and Basin-3. Each flowline was surveyed by five GPS receivers, mounted atop stakes drilled in the glacier ice at $4 \mathrm{~km}$ intervals, numbered \#1-5 in upglacier direction (Fig. 2; Table 1). Maintenance and data retrieval took place in early May 2009 and 2010 during the annual ground-based field season and during a short visit in August 2009. The lower receivers were positioned in highly crevassed areas with a thin snow cover in May 2009, and hence weak snow bridges, prohibiting access to all receivers on Basin-3 (B3 \#1-5) and the lowermost one on Duvebreen (Duve \#1). Insufficient power-supply caused a gap in the observations between June and August 2009.

\subsection{Continuous Global Positioning System (GPS) observations}

We utilized single-frequency (L1 band) GPS receivers. Powered by a single $3.6 \mathrm{~V}$ lithium battery, the receivers operate unmaintained over time periods of 1 year or longer (van de Wal et al., 2008; den Ouden et al., 2010). The receivers switch on every hour for a period of $3 \mathrm{~min}$ to allow stabilization of the received satellite signals. Subsequently, positions are computed within the receiver and the geographical position and time are logged. Multi-path errors are reduced by employing an antenna design that minimizes signal reception from below. Post-processing capabilities are restricted by the limited information stored, i.e. we do not apply correction with respect to atmospheric effects such

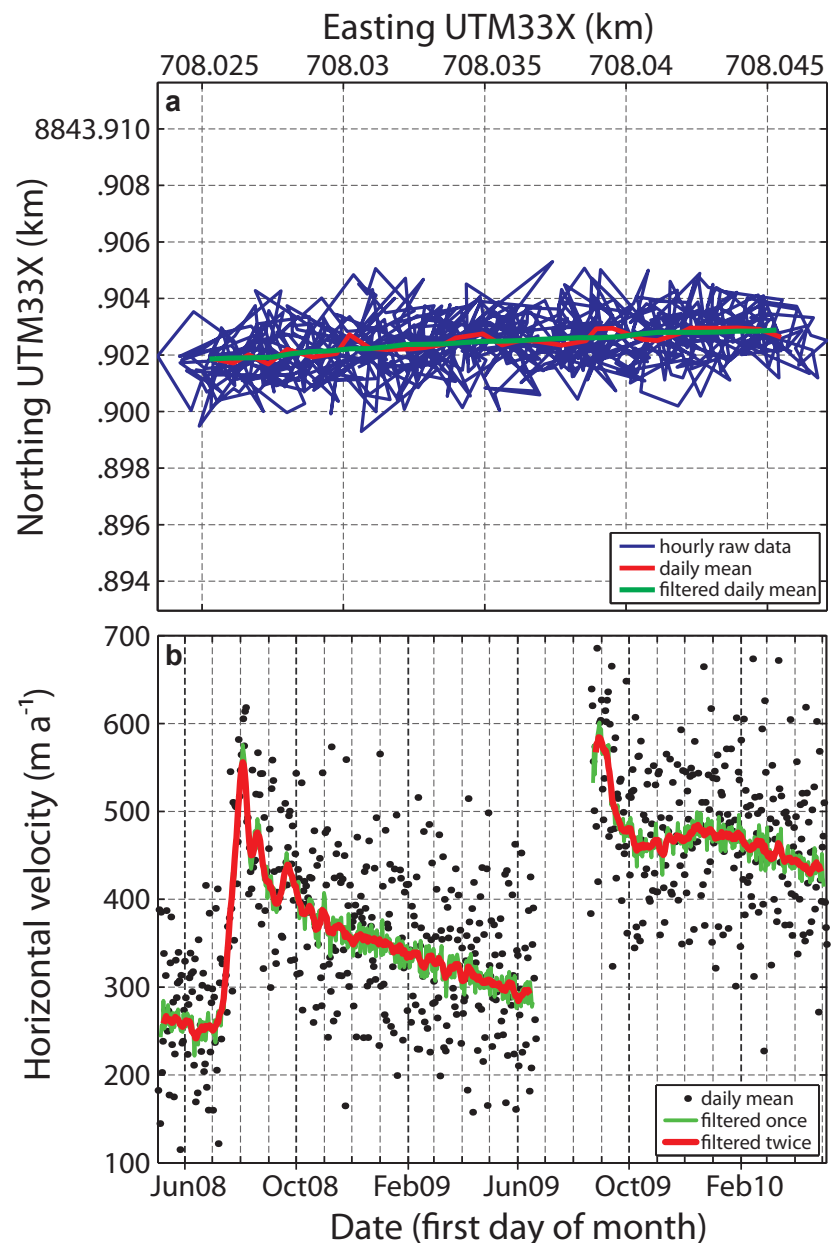

Fig. 3. Processing of continuous GPS observations. Positioning of stake Basin-3 \#2 during June 2008 (a): hourly GPS raw-data (blue), daily-mean values (red) and after application of a 7 day running mean (green). Flow velocities derived from displacement of GPS positions (b), utilizing daily mean (black scatters) or 7 day filtered positions with/without additional 7 day filtering of the computed velocities (red/blue solid lines).

as ionospheric and tropospheric delay, clock information or satellite configuration. Instead, the simple broadcast orbits with the WGS84 reference frame are used and a running average is applied to remove high frequency noise at the cost of temporal resolution.

The raw data consists of hourly records of the geographical position and the associated date and time. Outliers and data gaps are identified by determining the standard deviations within a moving time window of $72 \mathrm{~h}$. An hourly position is disregarded, if it raises the standard deviation of either the latitude or longitude above a specified threshold (e.g. 10\%). Outliers and data gaps may result from loss of power supply, bad satellite reception, e.g. due to riming of the antennas or external disturbances of the satellite signal, such as ionospheric effects. Daily displacements in the 
range of $0.1-1 \mathrm{~m}$ are within the uncertainty of the system's position estimates. Thus, data averaging over multiple days is required to yield meaningful results. The cleaned raw data is converted to UTM33X and a daily mean position (at hour 1200) is assigned, if at least 12 out of 24 samples of a particular day are available. The daily averages are characterized by significant noise reduction, compared to the hourly raw data (Fig. 3a). A 7 day running mean is applied independently to the daily Easting and Northing. This further enhances the robustness of the position measurement, however, at the cost of the temporal resolution. Daily displacements and hence velocities are calculated trigonometrically from the averaged positions. Considering the small horizontal scales discussed here, the curvature of the Earth can be neglected. Finally, the velocity record is smoothed by applying a second 7-day running-mean (Fig. 3b).

Based on the standard deviation of the average position of a reference station in central Spitsbergen during 2006-2009, the horizontal accuracy of the system was determined to be $1.62 \mathrm{~m}$ (den Ouden et al., 2010). Our measurement period largely overlaps with the period investigated by den Ouden et al. (2010) and is characterized by a solar ionospheric minimum. A larger error is expected in years with higher solar activity. Daily averaging has been shown to reduce the standard deviation in the position measurement to $<0.5 \mathrm{~m}$ (den Ouden et al., 2010). Accordingly, the maximum error in the displacement between consecutive days is $1 \mathrm{~m} \mathrm{~d}^{-1}$ $\left(365 \mathrm{~m} \mathrm{a}^{-1}\right)$. The error in displacement between two arbitrary daily mean positions, e.g. at the beginning and end of a 1 year period, remains unaffected and the accuracy increases significantly, i.e. to $1 \mathrm{~m} \mathrm{a}^{-1}$. Annual velocities according to the mean of the computed daily velocities differ from annual velocities inferred by the begin-end method by typically less than $1 \%$. Exceptions can be explained with incomplete records of daily values within a certain period. This indicates that the filtering of the GPS data provides robust estimates of ice-surface velocities. Given considerable noise level on short timescales (1 day to a few weeks), we cannot exclude the presence of spurious waves, similar to those described by den Ouden et al. (2010). Consequently, we do not interpret periodic fluctuations of smaller amplitude $\left(\lesssim 30 \mathrm{~m} \mathrm{a}^{-1}\right)$.

\subsection{Additional data}

Low-frequency ground-penetrating radar (GPR) and groundbased kinematic Global Navigation Satellite System (GNSS; GPS and GLONASS) observations were collected in spring 2008 and combined to derive glacier geometry along the flowlines. Where GPR measurements are lacking, bedrock elevations are interpolated utilizing additional information from a bedrock map at $1 \mathrm{~km}$ horizontal resolution (Dunse et al., 2011). A detailed description of the methodology is provided in Appendix A.

The air temperature record from an automatic weather station (AWS), located in the western part of Austfonna at
510 ma.s.1., (Fig. 1a; Schuler et al., 2007) is used to derive time series of cumulative positive degree-days (PDD) over the summer months. The annual PDD is the sum of daily mean air temperatures above melting over the period of an entire melt season (counted in ${ }^{\circ} \mathrm{Cd}$ ) and an indicator for surface melt (Reeh, 1989). The temperature record is not modified to account for the specific location or surface elevation of individual stakes, e.g. by application of a temperature lapse rate. Doing so, would result primarily in a shift in the absolute PDD values, but would not affect the timing of significant melt periods.

\section{Results}

\subsection{Ice-surface velocities: $2008 / 2009$ vs. $2009 / 2010$}

The GPS records span the time period from May 2008 to May 2010 and allow investigation of seasonal and interannual changes in ice-surface velocities. Over the measurement period, ice-surface velocities decreased with distance upglacier along the central flowlines (Fig. 4). In 2008, a prominent summer speed-up occurred at all stations on Basin-3 (Fig. 4a). Subsequently, ice-surface velocities gradually decreased from their summer maxima but maintaining relatively high speeds during the winter months compared to the pre-summer minimum, occurring in June. Monthly mean velocities in June 2009 were up to $23 \%$ faster than those observed in June 2008, except for the lowermost site, where velocities did not change significantly. Due to missing data, the 2009 summer speed-up of Basin-3 was not captured, but measured velocities from late summer 2009 until May 2010 appear to be shifted to higher values, compared to the corresponding period of the previous year. Over the time period May 2008 to May 2009, annual mean velocities inferred by the begin-end method ranged from $\sim 120 \mathrm{~m} \mathrm{a}^{-1}$ at B3 \#5 to $\sim 400 \mathrm{~m} \mathrm{a}^{-1}$ at B3\#1 (Table 2). Over the subsequent period May 2009-2010, annual mean velocities increased by 21$41 \%$.

At Duvebreen, ice-surface velocities maintained a relatively steady level over the two-year period. Short-lived summer speed-ups were only noticeable at the lower locations (Fig. 4b), i.e. within a few weeks after the summer maximum, velocities returned to just above pre-summer values. Annual mean velocities ranged from $40 \mathrm{~m} \mathrm{a}^{-1}$ at Duve $\# 5$ to $200 \mathrm{~m} \mathrm{a}^{-1}$ at Duve \#1. In 2009/2010, the annual mean velocity decreased by ca. $10 \%$ at the lowermost stake (Duve\#1), compared to 2008/2009, while velocities at the other measured locations (Duve \#2-4) did not change significantly. The GPS receiver at Duve \#5 did not function in 2009/2010.

\subsection{Summer speed-up 2008 and 2009}

Ice-surface velocities at Basin-3 underwent a clear annual cycle with lowest velocities preceding a prominent summer speed-up (Fig. 4). During June, the velocities fluctuated 

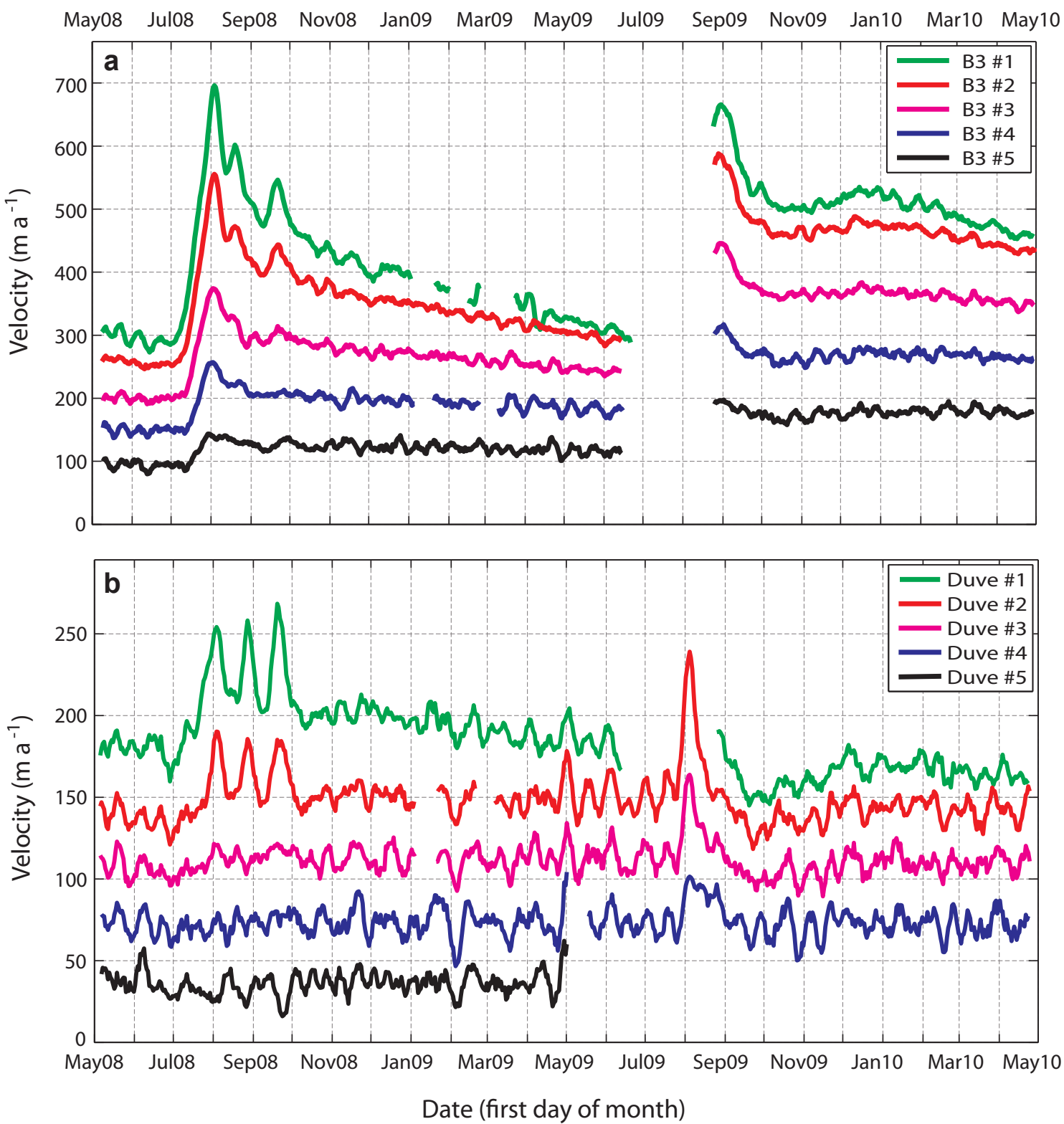

Fig. 4. Flow velocities along the central flowline of Basin-3 (a) and Duvebreen (b), during May 2008-2010.

around a low, stable level. The associated monthly means and standard deviations provide a reference against which to compare maximum summer velocities. We define the onset of the summer speed-up at a particular location as the day when velocities exceed three standard deviations from the pre-summer mean. This threshold determines velocities significantly above the winter background. We have tested the resolving power of our smoothed velocity time series by inserting an artificial speed-up event in the winter background of our recorded GPS data, assuming exponential acceleration and deceleration. Based on 100 realizations with randomly chosen event-lengths (2-7 days) and amplitudes (0.5$2 \mathrm{ma}^{-1}$ ), we assign a conservative timing error of \pm 3 days to both the onset dates and timing of velocity maxima. Despite this uncertainty in resolving power, the 2008 summer speed-ups appeared to be initiated at the lower locations and occurred progressively later at the stations located farther upglacier (Figs. 5 and 6). The summer maximum, however, was reached at about the same time at all locations of a particular flowline (Table 3).

The 2008 summer speed-up of Basin-3 was detected at all locations with a onset-delay of 11 days at the highest location (B3 \#5) compared to the lowermost sites (B3 \#1 \& 2; Fig. 5a). The maximum summer velocity was detected 9-25 days after the onset date, in the beginning of August (29 July-3 August) and ranged from $143 \mathrm{ma}^{-1}$ to $698 \mathrm{~m} \mathrm{a}^{-1}$. This corresponds 
Table 2. Annual mean velocities for the period May 2008-2009 and May 2009-2010 based either on all available daily values ( $V_{\text {mean }}$ ) or the first and last day's position at the beginning and end of the respective year $\left(V_{\mathrm{be}}\right)$. The velocity factor, $V_{\text {fac }}$, refers to current vs. previous year's $V_{\text {be }}$. At Basin-3, data is lacking between $\sim 15$ June-25 August, including both the pre-summer minimum and summer speed-up/maximum. The corresponding entry for $V_{\text {mean }}$ is marked by ${ }^{\text {a }}$.

\begin{tabular}{|c|c|c|c|c|c|}
\hline $\begin{array}{l}\text { Stake } \\
\text { (no.) }\end{array}$ & $\begin{array}{c}\text { Period } \\
\mathrm{dd} / \mathrm{mm} / \text { yyyy }\end{array}$ & $\begin{array}{l}\text { Flow dir. } \\
\text { (' azimuth) }\end{array}$ & $\begin{array}{c}\mathbf{V}_{\text {mean }} \\
\left(\mathrm{ma}^{-1}\right)\end{array}$ & $\begin{array}{c}\mathbf{V}_{\mathrm{be}} \\
\left(\mathrm{ma}^{-1}\right)\end{array}$ & $\mathbf{V}_{\text {fac }}$ \\
\hline B3 \#1 & 04/05/2008-30/04/2009 & 73 & $416 \pm 99$ & 403 & - \\
\hline B3 \#2 & 04/05/2008-30/04/2009 & 88 & $349 \pm 66$ & 349 & - \\
\hline B3 \#3 & 05/05/2008-30/04/2009 & 98 & $265 \pm 39$ & 264 & - \\
\hline B3 \#4 & 05/05/2008-30/04/2009 & 118 & $191 \pm 26$ & 190 & - \\
\hline B3 \#5 & 05/05/2008-30/04/2009 & 120 & $118 \pm 14$ & 117 & - \\
\hline B3 \#1 & 01/05/2009-30/04/2010 & 71 & $479 \pm 86^{\mathrm{a}}$ & 485 & 1.21 \\
\hline B3 \#2 & 01/05/2009-30/04/2010 & 87 & $444 \pm 69^{a}$ & & \\
\hline B3 \#3 & 01/05/2009-30/04/2010 & 97 & $350 \pm 49^{a}$ & 350 & 1.32 \\
\hline B3 \#4 & 01/05/2009-30/04/2010 & 117 & $256 \pm 34^{\mathrm{a}}$ & 255 & 1.34 \\
\hline B3 \#5 & 01/05/2009-30/04/2010 & 118 & $168 \pm 24^{a}$ & 165 & 1.41 \\
\hline Duve \#1 & 01/05/2008-30/04/2009 & 296 & $199 \pm 19$ & 198 & - \\
\hline Duve \#2 & 01/05/2008-30/04/2009 & 344 & $150 \pm 13$ & 149 & - \\
\hline Duve \#3 & 01/05/2008-30/04/2009 & 357 & $111 \pm 7$ & 110 & - \\
\hline Duve \#4 & 01/05/2008-30/04/2009 & 356 & $73 \pm 8$ & 72 & - \\
\hline Duve \#5 & 01/05/2008-30/04/2009 & 346 & $36 \pm 7$ & 32 & - \\
\hline Duve \#1 & 01/05/2009-26/04/2010 & 296 & $168 \pm 11$ & 174 & 0.88 \\
\hline Duve \#2 & 01/05/2009-27/04/2010 & 342 & $147 \pm 17$ & 147 & 0.98 \\
\hline Duve \#3 & 01/05/2009-27/04/2010 & 357 & $112 \pm 11$ & 111 & 1.00 \\
\hline Duve \#4 & 01/05/2009-26/04/2010 & 356 & $74 \pm 9$ & 74 & 1.03 \\
\hline Duve \#5 & 01/05/2009-04/05/2009 & 360 & - & - & - \\
\hline
\end{tabular}

Table 3. Characteristics of the summer speed-up, following the pre-summer minimum in June, $V_{\mathrm{JUN}}$, in terms of the onset date, timing and value of measured maximum velocities, $V_{\max }$, and the normalized maximum flow enhancement relative to pre-summer velocities, $V_{\text {fac }}$.

\begin{tabular}{lccccc}
\hline $\begin{array}{l}\text { Stake } \\
\text { (no.) }\end{array}$ & $\begin{array}{c}\mathbf{V}_{\mathrm{JUN}} \\
\left(\mathrm{m} \mathrm{a}^{-1}\right)\end{array}$ & $\begin{array}{c}\text { Onset } \\
(\mathrm{dd} / \mathrm{mm} / \text { yyyy })\end{array}$ & $\begin{array}{c}\text { Summer max. } \\
(\mathrm{dd} / \mathrm{mm} / \mathrm{yyyy})\end{array}$ & $\begin{array}{c}\mathbf{V}_{\max } \\
\left(\mathrm{m} \mathrm{a}^{-1}\right)\end{array}$ & $\begin{array}{c}\mathbf{V}_{\text {fac }} \\
\left(V_{\mathrm{max}} / V_{\mathrm{JUN}}\right)\end{array}$ \\
\hline B3\#1 & $291 \pm 9$ & $09 / 07 / 2008$ & $03 / 08 / 2008$ & 698 & 2.40 \\
B3\#2 & $253 \pm 6$ & $09 / 07 / 2008$ & $03 / 08 / 2008$ & 556 & 2.20 \\
B3\#3 & $199 \pm 4$ & $13 / 07 / 2008$ & $02 / 08 / 2008$ & 374 & 1.88 \\
B3\#4 & $149 \pm 5$ & $17 / 07 / 2008$ & $02 / 08 / 2008$ & 257 & 1.72 \\
B3\#5 & $93 \pm 6$ & $20 / 07 / 2008$ & $29 / 07 / 2008$ & 143 & 1.53 \\
Duve\#1 & $178 \pm 7$ & $21 / 07 / 2008$ & $03 / 08 / 2008$ & 254 & 1.43 \\
Duve\#2 & $135 \pm 6$ & $28 / 07 / 2008$ & $03 / 08 / 2008$ & 190 & 1.41 \\
Duve\#3 & $105 \pm 5$ & $01 / 08 / 2008$ & $01 / 08 / 2008$ & 122 & 1.16 \\
Duve\#4 & $71 \pm 8$ & - & - & - & - \\
Duve\#5 & $38 \pm 9$ & - & - & - & - \\
Duve\#1 & $181 \pm 10$ & - & - & - & - \\
Duve\#2 & $151 \pm 9$ & $29 / 07 / 2009$ & $04 / 08 / 2009$ & 239 & 1.59 \\
Duve\#3 & $113 \pm 9$ & $31 / 07 / 2009$ & $04 / 08 / 2009$ & 164 & 1.45 \\
Duve\#4 & $75 \pm 7$ & $01 / 08 / 2009$ & $04 / 08 / 2009$ & 102 & 1.36 \\
Duve\#5 & - & - & - & - & - \\
Timing error & - & \pm 3 days & \pm 3 days & - & - \\
\hline
\end{tabular}



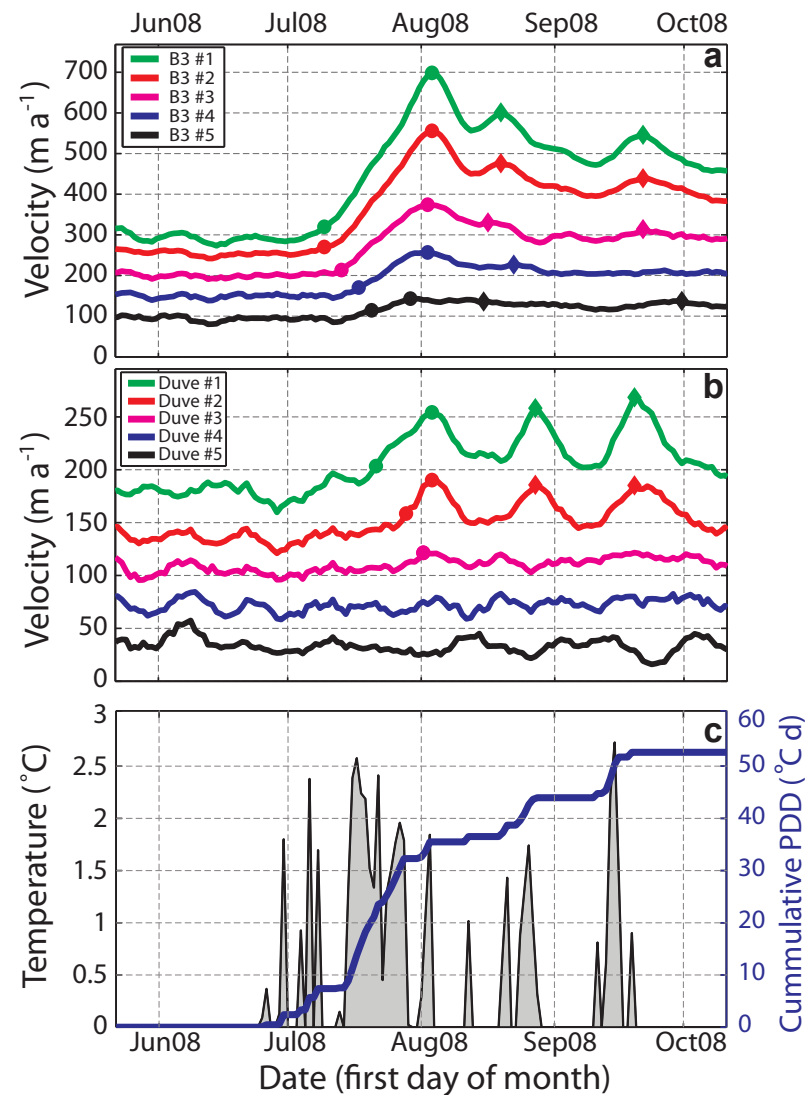

Fig. 5. Summer speed-up along the central flowline of Basin-3 (a) and Duvebreen (b) in summer 2008. Markers indicate the occurrence of the onset of summer speed-up and three separate velocity peaks (see also Table 3). Positive daily mean air temperature and cumulative PDD at the AWS on Etonbreen is shown in (c).

to a velocity increase of $53-140 \%$ compared to the presummer mean. The relative acceleration is smallest at the uppermost station and increases farther downglacier.

At Duvebreen, the 2008 summer speed-up was less pronounced (16-43\% acceleration compared to the pre-summer minimum) and only detected at the three lowermost sites along the flowline (Duve\#1-3; Fig. 5b). The 2009 summer speed-up at these locations was of higher amplitude (up to $59 \%$ at Duve \#2; Table 3) and also detected farther upglacier than in 2008.

The temperature record of the AWS revealed maximum diurnal temperatures up to $\sim 2.5^{\circ} \mathrm{C}$ in summer 2008 and a cumulative PDD of $52^{\circ} \mathrm{Cd}$. Throughout summer 2009, the PDD-value was significantly larger, $78^{\circ} \mathrm{C} \mathrm{d}$, and maximum temperatures reached $\sim 3.5^{\circ} \mathrm{C}$. The 2008 summer speed-up was characterized by 3 distinct peaks, concurrent at all locations, except for the second speed-up event that followed $\sim 2$ weeks after the primary summer maxima in case of Basin-3 and $\sim 3$ weeks in case of Duvebreen. The third and last speed-up event during summer 2008 followed $\sim 7$ weeks after the primary summer maximum (Fig. 5a, b). The initial

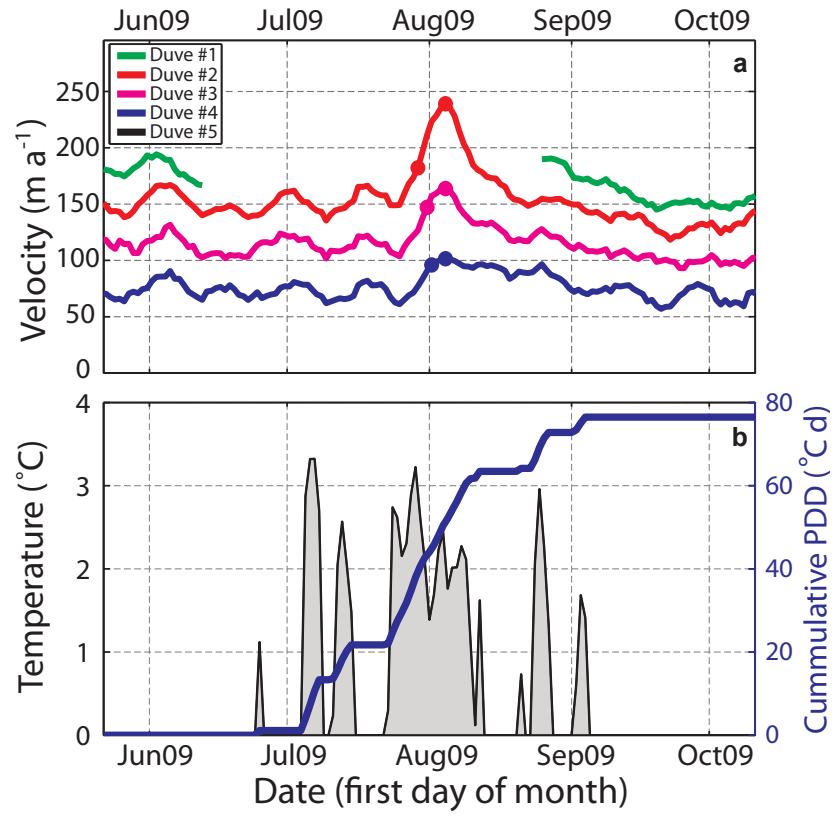

Fig. 6. Summer speed-up along the central flowline of Duvebreen in summer 2009 (a) with markers indicating the occurrence of onset of summer speed-up and peak velocity. Positive daily mean air temperature and cumulative PDD is shown in (b).

summer speed-up coincided with the first prolonged period with air temperatures above $0^{\circ} \mathrm{C}$ in the second half of July (Fig. 5c). The two other velocity peaks coincided with a second and third period of melting that lead to a significant rise in cumulative PDD. Only one single speed-up event was observed at Duvebreen throughout summer 2009, coincident with the major melt period. A subsequent period of observed positive air temperatures does not appear to significantly enhance flow velocities (Fig. 6).

\section{Discussion}

\subsection{Surface-velocities fluctuations}

We will first discuss the characteristics of the observed summer speed-ups, then point out particularities in the dynamics of the two flow units. Finally, we will propose an explanation for the observed interannual and longterm velocity changes. Our observations from two outlet glaciers of Austfonna suggest that seasonal velocity changes are closely linked to the timing and total volume of surface-generated meltwater and hence, mainly driven by basal lubrication. Our observations are in line with previous studies in the Alps (Iken, 1981), and in the Arctic, such as Alaska (Kamb et al., 1994), the Canadian Arctic (Copland et al., 2003), Svalbard (Nuttall and Hodgkins, 2005), the Greenland Ice Sheet (Zwally et al., 2002) and a rising number of its outlet glaciers (e.g. Joughin et al., 2008; Bartholomew et al., 2010). 
Summer 2008 was characterized by relatively low air temperatures, yielding a low cumulative PDD and hence, little surface melt. Snow cover persisted over the ice cap throughout the entire summer season and is likely to have maintained high surface albedo, thereby reducing the energy available for melt. The input of small volumes of melt water to the subglacial system may not have been sufficient to establish an efficient drainage system (Iken and Bindschadler, 1986; Nienow et al., 1998). Consequently, renewed melt water input during late-summer melt periods, associated with a distinct increase in cumulative PDD, presumably promote high subglacial water pressure and enhanced hydraulic lubrication. The asynchrony in the second speed-up event on Basin-3 and Duvebreen may be explained by different local weather situations on the northern and southern side of the ice cap, which may not be equally well represented in a single temperature record. In addition, spatially variable rainfall may have contributed to differently enhance the water input and hence basal motion, at the two sites (Fudge et al., 2009). For both flowlines, an upglacier propagation of the onset of the 2008 summer speed-up was observed. This can be explained by a later onset of surface melt and hence delayed local input of meltwater into the englacial/subglacial drainage system, as recently also observed on Greenland outlet glaciers (Andersen et al., 2010; Bartholomew et al., 2011a; Sole et al., 2011). Reduced meltwater production at higher elevation may explain the dampened amplitude of the velocity peaks at stakes farther upglacier (Andersen et al., 2010).

In 2009, air temperatures were significantly higher, yielding a cumulative PDD of $78^{\circ} \mathrm{Cd}$, compared to only $52^{\circ} \mathrm{C} \mathrm{d}$ in 2008 . The summer speed-up in 2009 coincided with a strong increase in cumulative PDD. The detected delay in speed-up at locations upglacier (4 days between Duve \#2 \& 4) is hardly significant. A second noticeable melt period in the end of August had no clear effect on the observed surface motion, in contrast to comparable melt periods in 2008. This indicates that after the major melt period in 2009, the basal drainage system was able to accommodate the increased input of meltwater likely associated with the warm events, without weakening the ice-bed coupling and promoting enhanced basal motion (Bartholomaus et al., 2008, 2011). Recent numerical modelling (Schoof, 2010; Pimentel and Flowers, 2011) showed that under sustained meltwater supply, the evolvement of an efficient hydraulically drainage system may significantly reduce the basal water pressure and its sensitivity to changing water inputs.

Particular for the velocity timeseries from Basin-3 is the slow and gradual decrease from the summer-2008 velocity maxima. This indicates that basal water pressures remained high and only decreased gradually. An inefficient drainage system, e.g. a layer of subglacial sediments may have retained a significant fraction of water throughout the winter months, thereby facilitating continuously high, but diminishing deformation of water-saturated sediments (Tulaczyk et al., 2000; Fischer and Clarke, 2001; Bougamont et al., 2011). The bedrock slope along the surveyed profile is gentle and lies below sea level along its entire length, providing little topographic resistance to basal sliding and facilitating upglacier propagation of velocity fluctuations through longitudinal coupling. This may explain why the summer speed-up is noticeable at all locations, albeit at decreasing amplitude farther upglacier.

At Duvebreen, the multiple summer speed-ups in 2008 and the single one in 2009 were short-lived in nature. The surface velocity quickly returned to pre-summer values. This may be explained by a rapid transition from a hydraulically inefficient, distributed drainage system to a hydraulically efficient, channelized system. Another explanation is provided by the specific topography, which is fundamentally different from that of Basin-3. At the uppermost 3 stakes on Duvebreen (Duve \#3-5) the glacier is grounded about $100 \mathrm{~m}$ a.s.1. (Fig. 2). Duve \#2 is located just downglacier of a steep drop into the narrow Duvefjord, where bedrock elevations reach deeper than $-100 \mathrm{~m}$ a.s.l. (Duve\#1). The steep valley walls may cause significant lateral drag upon the lower section of the glacier, i.e. below Duve \#2 (Nye, 1965; Raymond, 1996). Additional basal lubrication has to compensate for the lateral drag. This may only be fulfilled in periods when the basal water pressure exceeds a certain threshold. Lateral shear may thus stabilize the terminus of Duvebreen and make the glacier less prone to terminus fluctuations and/or longitudinal coupling of changes in terminus dynamics. The steep bedrock topography at Duve \#2 promotes the formation of closely-spaced surface crevasses, as observed in the field, facilitating meltwater routing to the bed. Enhanced response to melt-induced acceleration was recently also reported for the heavily crevassed terminus of Helheim Galcier, East Greenland (Andersen et al., 2010). In 2009, surface melt and input of meltwater into the englacial/subglacial drainage system may have occurred also at higher elevation, where individual crevasses have been observed, causing noticeable summer speed-up also at higher stations.

Finally, we propose factors that may explain the observed interannual acceleration of Basin-3, i.e. 2009/2010 compared to $2008 / 2009$, as well as the longterm velocity increase since the mid 1990s. The main contribution to fast flow of grounded glaciers is generally attributed to basal motion (e.g. Clarke, 1987). Changes in basal resistance to glacier flow therefor provide the most likely explanation for the observed changes and may be associated with changes in thermal and hydrological conditions at the ice-bed interface. There is multiple evidence of the presence of subglacial sediments beneath the marine grounded, southeastern regions of Austfonna (Dowdeswell et al., 1999). Changes in water saturation of subglacial sediments could play an important role in the observed dynamic changes of Basin-3, facilitating sediment deformation to a varying degree (Tulaczyk et al., 2000; Fischer and Clarke, 2001; Bougamont et al., 2011). However, this remains purely speculative, as no direct information on 
the basal conditions are available. Given the fact that the outlet glaciers of Austfonna are well grounded, we regard potential changes in oceanic forcing to have only minor effects on ice velocity changes. Mechanisms that are known to affect the calving rate of some outlet glaciers of Greenland, and hence also influence the backstress at, and flow velocities of the terminus, include the formation of seasonal ice mélange (Amundson and Truffer, 2010; Howat et al., 2010) or temporal floatation of the terminus (Howat et al., 2007); both of which are not known to act upon Austfonna. Basin-3 surged more than 140 years ago. The observed longterm increase in velocity may be indicative for renewed surge activity, similar to a general speed-up of Variegated Glacier, Alaska, prior to its surge (Raymond, 1987).

\subsection{Implications for iceberg calving}

Changes in the dynamics of marine terminating glaciers have a direct impact on the iceberg discharge. The calving flux, $q_{\mathrm{c}}$, is determined by the ice flux through the calving front and the position change of the front. Following van der Veen (1996) the calving flux can be expressed as:

$q_{\mathrm{c}}=\left(\bar{u}_{\mathrm{c}}-\frac{d L}{d t}\right) \cdot h w$

where $\bar{u}_{\mathrm{c}}$ is the depth-averaged velocity at the calving front, $\frac{d L}{d t}$ the change in front position over time (positive in case of advance) and $h$ and $w$ are the vertical and horizontal dimensions of the calving front.

Using the InSAR-derived surface velocities, Dowdeswell et al. (1999) investigated the ice flux within the flow unit of Basin-3. Estimating the cross-sectional area to $5 \times 0.24 \mathrm{~km}^{2}$, $\sim 7.5 \mathrm{~km}$ upglacier from the marine ice margin, and assuming a depth-averaged velocity corresponding to $85 \%$ of the measured surface velocity, i.e. $90 \mathrm{~m} \mathrm{a}^{-1}$ in winter 1992 and $50 \mathrm{~m} \mathrm{a}^{-1}$ in winter 1994, the ice flux amounted to 0.1 and $0.05 \mathrm{Gt} \mathrm{a}^{-1}$, respectively. Dowdeswell et al. (2008) provided a total calving estimate for Austfonna, distinguishing between the ice-flux through the calving front and marginchange flux contribution of individual basins. The calving flux from Basin-3 was dominated by marginal retreat, accounting for $0.3 \mathrm{Gta}^{-1}$ out of a total $0.45 \mathrm{Gta}^{-1}$. The ice flux through the calving front contributed $0.15 \mathrm{Gta}^{-1}$. The calving flux from Duvebreen was dominated by the ice-flux contribution, accounting for $\sim 75 \%$ of a total calving flux of $0.1 \mathrm{Gta}^{-1}$.

Dowdeswell et al. $(1999,2008)$ considered their annual ice flux estimates to represent a lower limit, because flow rates during the winter months December to February, corresponding to the acquisition period of the SAR data used, are usually lower than the annual average. However, our twoyear record indicates that velocities in December to February are approximately equal or, in case of Basin-3 over the period 2009-2010, even slightly larger than the corresponding annual average (Fig. 4). Mean-annual velocities
2009/2010 of $479 \mathrm{ma}^{-1}$ at B3\#1 and $444 \mathrm{ma}^{-1}$ at B3\#2 (Table 2), about $4-5 \mathrm{~km}$ and $8-9 \mathrm{~km}$ from the marine margin, indicate a more than four-fold velocity increase compared to those used to derive previous ice flux estimates. Applied to the fluxgate defined by Dowdeswell et al. (1999), the ice flux within Basin-3 increased from $0.1 \mathrm{Gt} \mathrm{a}^{-1}$ in 1992 to $0.45 \mathrm{Gt} \mathrm{a}^{-1}$ in 2009/2010, indicating that the ice flux contribution may have surpassed the contribution from marginal retreat. The flow velocities along the central flowline of $\mathrm{Du}-$ vebreen doubled from $20-80 \mathrm{~m} \mathrm{a}^{-1}$ in the mid-1990s to 35$200 \mathrm{~m} \mathrm{a}^{-1}$ in 2008-2010, also suggesting an increased iceflux contribution to the total calving flux. New data on the marine outline is required to assess the total calving flux.

\section{Conclusions}

In 2008, the observed summer speed-up of both Basin-3 and Duvebreen appears closely linked to positive diurnal air temperatures/cumulative PDD, a proxy for surface melt and potential input of meltwater into the englacial/subglacial drainage system. In 2009, GPS observations only cover the speed-up of Duvebreen. Summer 2009 was significantly warmer than summer 2008 with a pronounced principle melt period (late July to early August) and the relationship between ice-surface velocity and air temperature is more complex. Meltwater volumes produced later in the melt season do not lead to positive excursions in glacier flow. This indicates that a hydraulically effective drainage system has established in the course of the principle melt period and increased meltwater input can therefore be accommodated without raising basal water pressure and enhancing basal lubrication.

Annual mean and mean winter flow velocities of Duvebreen over the period 2008-2010 were twice as high as those inferred for winter in the 1990s. The spatial velocity pattern and the characteristics of summer speed-up appear to be controlled by the distinct topography with the lower part of the glacier flowing over an escarpment and being channelled into a deep and narrow fjord. Likewise, Basin-3 has accelerated by about a factor of four compared to the 1990s and also showed an acceleration of $30-40 \%$ from $2008 / 2009$ to 2009/2010. Velocities measured during summer 2008 reach up to $700 \mathrm{~m} \mathrm{a}^{-1}\left(2 \mathrm{~m} \mathrm{~d}^{-1}\right)$ within $5 \mathrm{~km}$ from the calving front and are almost as high as those reported from Kronebreen, often referred to as the fastest tidewater glacier on Svalbard, with annual mean velocities up to $550 \mathrm{~m} \mathrm{a}^{-1}\left(1.5 \mathrm{~m} \mathrm{~d}^{-1}\right.$; Lefauconnier et al., 1994) and recent summer maxima of $900 \mathrm{~m} \mathrm{a}^{-1}\left(2.5 \mathrm{~m} \mathrm{~d}^{-1}\right)$ measured at the calving front (Rolstad et al., 2009).

We propose that the observed longterm velocity changes are attributed to changes in thermal and hydrological conditions at the ice-bed interface, in combination with lithological and topographic characteristics. The significant acceleration of Basin-3 indicates that this outlet glacier possibly undergoes initiation of renewed surge activity. Continued GPS 
observations along the central flowline and spatial continuous satellite observations are currently analyzed to further elucidate the dynamic state of Basin-3.

\section{Appendix A}

\section{Derivation of glacier geometry along flowlines}

To derive the glacier geometry along the flowlines, we combine surface elevation profiles from ground-based kinematic GNSS with low-frequency GPR measurements of ice thickness. Kinematic GNSS observations were logged at a rate of $1 \mathrm{~Hz}$ (approx. every $5.5 \mathrm{~m}$ ) and differentially post-processed using a stationary GNSS as reference, yielding an accuracy of typically better than $5 \mathrm{~cm}$ in horizontal position and $10 \mathrm{~cm}$ in height (Eiken et al., 1997). GPR (VIRL-6) measurements were triggered every $2 \mathrm{~m}$ by means of an odometer. Navigation data were recorded simultaneously with the GPR data using a GPS Garmin II Plus receiver (Vasilenko et al., 2010). The radar transmitter generates pulses of $25 \mathrm{~ns}$ duration with a center frequency of $20 \mathrm{MHz}$, resulting in a system resolution of approximately $2 \mathrm{~m}$ (assuming a radio-wave velocity of $0.168 \pm 0.0005 \mathrm{~m} \mathrm{~ns}^{-1}$, typical for cold ice). The precision of the ice thickness measurements was estimated to $\sim 1.6 \mathrm{~m}$, based on the standard deviation in ice thickness at more than 34000 crossover points from the entire Austfonna survey (personal communication G. Moholdt, Department of Geosciences, University of Oslo, Oslo, Norway, 2011). The precision represents the error in ice thickness due to the uncertainty in the time measurement (digitization of bedrock reflection). The accuracy in ice thickness is determined when adding an absolute error of about $0.3 \%$ (3 mm per meter ice) to the precision value. This absolute error is related to the uncertainty of radio-wave velocity. For an ice thickness of $350 \mathrm{~m}$ this corresponds to an error of about $1 \mathrm{~m}$ $\left(2000 \mathrm{~ns} \times 0.0005 \mathrm{~m} \mathrm{~ns}^{-1}\right)$ yielding an accuracy of the GPRderived ice thickness of about $2.6 \mathrm{~m}$.

To link kinematic GPS and GPR measurements along the flowline, linear segments between consecutive stake positions have been taken as benchmark distance. A correction factor, specific for each dataset and leg (typically between 0.98 and 1) is then applied to all distance increments so that the cumulative distance along the measured tracks matches the benchmark distance. Both datasets are resampled at $10 \mathrm{~m}$ intervals to allow subtraction of ice thickness from surface elevation to derive bedrock elevation. Gaps in the GPR record are padded by extracting values from an ice thickness map at $1 \mathrm{~km}$ horizontal resolution (Dunse et al., 2011). Values were extracted for positions corresponding to $1 \mathrm{~km}$ intervals along the flowlines and corrected for a mean bias, determined from the overlapping sections (mean and standard deviation of $-16.61 \pm 11.59 \mathrm{~m}$ in the case of Basin- $3 ;-1.11 \pm 7.80 \mathrm{~m}$ in the case of Duvebreen).
Acknowledgements. This study is a contribution to the International Polar Year project GLACIODYN funded by the Norwegian Research Council (grant 176076/S30). The final stage was supported by funding to the ice2sea project from the European Union 7th Framework Programme, grant number 226375, ice2sea contribution number 029. T. Dunse was supported by an Arctic field grant through the Svalbard Science Forum (field work). We thank G. Moholdt and M. Sund for assistance in retreiving the GPS data. E. Vasilenko and F. Navarro are greatly acknowledged for collecting low-frequency GPR data along the flowlines and extracting bedrock information. We thank editor I. M. Howat and reviewers M. King, G. S. Hamilton, P. Christoffersen and one anonymous reviewer for thorough and encouraging reviews that helped to improve this paper.

Edited by: I. M. Howat

\section{References}

Amundson, J. M. and Truffer, M.: A unifying framework for iceberg-calving models, J. Glaciol., 56, 822-830, doi:10.3189/002214310794457173, 2010.

Andersen, M. L., Larsen, T. B., Nettles, M., Elosegui, P., van As, D., Hamilton, G. S., Stearns, L. A., Davis, J. L., Ahlstrøm, A. P., de Juan, J., Ekström, G., Stenseng, L., Khan, S. A., Forsberg, R., and Dahl-Jensen, D.: Spatial and temporal melt variability at Helheim Glacier, East Greenland, and its effect on ice dynamics, J. Geophys. Res.-earth Surface, 115, F04041, doi:10.1029/2010JF001760, 2010.

Bamber, J., Krabill, W., Raper, V., and Dowdeswell, J.: Anamolous recent growth of part of a large Arctic ice cap: Austfonna, Svalbard, Geophys. Res. Lett., 31, L12402, doi:10.1029/2004GL019667, 2004.

Bartholomaus, T. C., Anderson, R. S., and Anderson, S. P.: Response of glacier basal motion to transient water storage, Nature Geosci., 1, 33-37, doi:10.1038/ngeo.2007.52, 2008.

Bartholomaus, T., Anderson, R., and Anderson, S.: Growth and collapse of the distributed subglacial hydrologic system of Kennicott Glacier, Alaska, USA, and its effects on basal motion, JG, 57, 985-1002, 2011.

Bartholomew, I., Nienow, P., Mair, D., Hubbard, A., King, M. A., and Sole, A.: Seasonal evolution of subglacial drainage and acceleration in a Greenland outlet glacier, Nature Geosci., 3, 408411, doi:10.1038/NGEO863, 2010.

Bartholomew, I., Nienow, P., Sole, A., Mair, D., Cowton, T., King, M., and Palmer, S.: Seasonal variations in Greenland Ice Sheet motion: Inland extent and behaviour at higher elevations, Earth Planet. Sci. Lett., 307, 271-278, doi:10.1016/j.epsl.2011.04.014, 2011a.

Bartholomew, I., Nienow, P., Sole, A., Mair, D., Cowton, T., Palmer, S., and Wadham, J.: Supraglacial forcing of subglacial drainage in the ablation zone of the Greenland ice sheet, Geophys. Res. Lett., 38, L08502, doi:10.1029/2011GL047063, 2011 b.

Bevan, S., Luckman, A., and Murray, T.: Positive mass balance during the late 20th century on Austfonna, Svalbard revealed using satellite interferometry, Ann. Glaciol., 46, 117-122, 2007.

Bougamont, M., Price, S., Christoffersen, P., and Payne, A. J.: Dynamic patterns of ice stream flow in a 3-D higher-order ice sheet 
model with plastic bed and simplified hydrology, J. Geophys. Res., 116, F04018, doi:10.1029/2011JF002025, 2011.

Clarke, G.: Fast glacier flow - ice streams, surging, and tidewater glaciers, J. Geophys. Res.-Solid Earth and Planets, 92, 88358841, 1987.

Clarke, G., Collins, S., and Thompson, D.: Flow, thermal structure, and subglacial conditions of a surge-type glacier, Can. J. Earth Sci., 21, 232-240, 1984.

Copland, L., Sharp, M. J., and Nienow, P. W.: Links between shortterm velocity variations and the subglacial hydrology of a predominantly cold polythermal glacier, J. Glaciol., 49, 337-348, 2003.

den Ouden, M. A. G., Reijmer, C. H., Pohjola, V., van de Wal, R. S. W., Oerlemans, J., and Boot, W.: Stand-alone single-frequency GPS ice velocity observations on Nordenskiöldbreen, Svalbard, The Cryosphere, 4, 593-604, doi:10.5194/tc-4-593-2010, 2010.

Dowdeswell, J.: Drainage-basin characteristics of Nordaustlandet ice caps, Svalbard, J. Glaciol., 32, 31-38, 1986.

Dowdeswell, J., Drewry, D., Cooper, A., Gorman, M., Liestøl, O., and Orheim, O.: Digital mapping of the Nordaustlandet ice caps from airborne geophysical investigations, Ann. Glaciol., 8, 5158, 1986.

Dowdeswell, J. A., Unwin, B., Nuttall, A. M., and Wingham, D. J.: Velocity structure, flow instability and mass flux on a large Arctic ice cap from satellite radar interferometry, Earth Planet. Sci. Lett., 167, 131-140, 1999.

Dowdeswell, J. A., Bassford, R. P., Gorman, M. R., Williams, M., Glazovsky, A. F., Macheret, Y. Y., Shepherd, A. P., Vasilenko, Y. V., Savatyuguin, L. M., Hubberten, H. W., and Miller, H.: Form and flow of the Academy of Sciences Ice Cap, Severnaya Zemlya, Russian High Arctic, J. Geophys. Res.-solid Earth, 107, 2076, doi:10.1029/2000JB000129, 2002.

Dowdeswell, J. A., Benham, T. J., Gorman, M. R., Burgess, D., and Sharp, M. J.: Form and flow of the Devon Island Ice Cap, Canadian Arctic, J. Geophys. Res.-earth Surface, 109, F02002, doi:10.1029/2003JF000095, 2004.

Dowdeswell, J. A., Benham, T. J., Strozzi, T., and Hagen, J. O.: Iceberg calving flux and mass balance of the Austfonna ice cap on Nordaustlandet, Svalbard, J. Geophys. Res.-Earth Surface, 113, F03022, doi:10.1029/2007JF000905, 2008.

Dunse, T., Greve, R., Schuler, T. V., and Hagen, J. O.: Permanent fast flow versus cyclic surge behaviour: numerical simulations of the Austfonna ice cap, Svalbard, J. Glaciol., 57, 247-259, 2011.

Eiken, T., Hagen, J. O., and Melvold, K.: Kinematic GPS survey of geometry changes on Svalbard glaciers, Ann. Glaciol., 24, 157$163,1997$.

Fischer, U. H. and Clarke, G. K. C.: Review of subglacial hydro-mechanical coupling: Trapridge Glacier, Yukon Territory, Canada, Quaternary International, 86, Int Union Quaternary Assoc, doi:10.1016/S1040-6182(01)00049-0, 2001.

Fudge, T. J., Harper, J. T., Humphrey, N. F., and Pfeffer, W. T.: Rapid glacier sliding, reverse ice motion and subglacial water pressure during an autumn rainstorm, Ann. Glaciol., 50, 101108,2009

Gudmundsson, G. H.: Transmission of basal variability to a glacier surface, J. Geophys. Res.-solid Earth, 108, 2253, doi:10.1029/2002JB002107, 2003.

Hagen, J., Liestøl, O., Roland, E., and Jørgensen, T.: Glacier Atlas of Svalbard and Jan Mayen, Norsk Polarinstitutt, Oslo, Norway,
1993.

Hagen, J., Eiken, T., Kohler, J., and Melvold, K.: Geometry changes on Svalbard glaciers: mass-balance or dynamic response?, Ann. Glaciol., 42, 255-261, 2005.

Howat, I. M., Joughin, I., and Scambos, T. A.: Rapid changes in ice discharge from Greenland outlet glaciers, Science, 315, 15591561, doi:10.1126/science.1138478, 2007.

Howat, I. M., Box, J. E., Ahn, Y., Herrington, A., and McFadden, E. M.: Seasonal variability in the dynamics of marineterminating outlet glaciers in Greenland, J. Glaciol., 56, 601$613,2010$.

Iken, A.: The Effect of the Subglacial Water-pressure On the Sliding Velocity of A Glacier In An Idealized Numerical-model, J. Glaciol., 27, 407-421, 1981.

Iken, A. and Bindschadler, R. A.: Combined Measurements of Subglacial Water-pressure and Surface Velocity of Findelengletscher, Switzerland - Conclusions About Drainage System and Sliding Mechanism, J. Glaciol., 32, 101-119, 1986.

Joughin, I., Das, S. B., King, M. A., Smith, B. E., Howat, I. M., and Moon, T.: Seasonal speedup along the western flank of the Greenland Ice Sheet, Science, 320, 781-783, 2008.

Kamb, B., B., Engelhardt, H., Fahnenstock, M. A., Humphrey, N., Meier, M., and Stone, D.: Mechanical and Hydrologic Basis For the Rapid Motion of A Large Tidewater Glacier .2. Interpretation, J. Geophys. Res.-solid Earth, 99, 15231-15244, doi:10.1029/94JB00467, 1994.

Korona, J., Berthier, E., Bernard, M., Rémy, F., and Thouvenot, E.: SPIRIT. SPOT 5 stereoscopic survey of Polar Ice: Reference Images and Topographies during the fourth International Polar Year (2007-2009), ISPRS J. Photogrammetry and Remote Sensing, 64, 204-212, doi:10.1016/j.isprsjprs.2008.10.005, 2009.

Lefauconnier, B. and Hagen, J.: Surging and Calving Glaciers in Eastern Svalbard, Norsk Polarinstitutt, Oslo, Norway, 1991.

Lefauconnier, B., Hagen, J., and Rudant, J.: Flow Speed and Calving Rate of Kongsbreen Glacier, Svalbard, Using Spot Images, Polar Research, 13, 59-65, 1994.

Lüthi, M., Funk, M., Iken, A., Gogineni, S., and Truffer, M.: Mechanisms of fast flow in Jakobshavn Isbrae, West Greenland: Part III. Measurements of ice deformation, temperature and crossborehole conductivity in boreholes to the bedrock, J. Glaciol., 48, 369-385, doi:10.3189/172756502781831322, 2002.

Meier, M. and Post, A.: What are glacier surges, Canadian Journal of Earth Sciences, 6, 807-817, 1969.

Meier, M. and Post, A.: Fast tidewater glaciers, J. Geophys. Res.Solid Earth and Planets, 92, 9051-9058, 1987.

Moholdt, G. and Kääb, A.: A new DEM of the Austfonna ice cap by combining differential SAR interferometry with ICESat laser altimetry, Polar Res., in press, 2012.

Moholdt, G., Hagen, J. O., Eiken, T., and Schuler, T. V.: Geometric changes and mass balance of the Austfonna ice cap, Svalbard, The Cryosphere, 4, 21-34, doi:10.5194/tc-4-21-2010, 2010.

Nick, F., Vieli, A., Howat, I., and Joughin, I.: Large-scale changes in Greenland outlet glacier dynamics triggered at the terminus, Nature Geosci., 2, 110-114, 2009.

Nienow, P., Sharp, M., and Willis, I.: Seasonal changes in the morphology of the subglacial drainage system, Haut Glacier d'Arolla, Switzerland, Earth Surface Processes and Landforms, 23, 825-843, 10.1002/(SICI)10969837(199809)23:9<825::AID-ESP893>3.0.CO;2-2, 1998. 
Nuttall, A. M. and Hodgkins, R.: Temporal variations in flow velocity at Finsterwalderbreen, a Svalbard surge-type glacier, Ann. Glaciol., 42, 71-76, 2005.

Nye, J.: The flow of a glacier in a channel of rectangular, elliptic or parabolic cross-section, J. Glaciol., 5, 661-699, 1965.

O’Neel, S., Echelmeyer, K. A., and Motyka, R.: Short-term variations in calving of a tidewater glacier: LeConte Glacier, Alaska, USA, J. Glaciol., 49, 587-598, 2003.

Pfeffer, W. T., Harper, J. T., and O’Neel, S.: Kinematic constraints on glacier contributions to 21 st-century sea-level rise, Science, 321, 1340-1343, 2008.

Pimentel, S. and Flowers, G. E.: A numerical study of hydrologically driven glacier dynamics and subglacial flooding, Proceedings of the Royal Society A-mathematical Physical and Engineering Sciences, 467, 537-558, doi:10.1098/rspa.2010.0211, 2011.

Pinglot, J., Hagen, J., Melvold, K., Eiken, T., and Vincent, C.: A mean net accumulation pattern derived from radioactive layers and radar soundings on Austfonna, Nordaustlandet, Svalbard, J. Glaciol., 47, 555-566, 2001.

Price, S. F., Payne, A. J., Catania, G. A., and Neumann, T. A.: Seasonal acceleration of inland ice via longitudinal coupling to marginal ice, J. Glaciol., 54, 213-219, 2008.

Raymond, C.: How do glaciers surge - a review, J. Geophys. Res.Solid Earth and Planets, 92, 9121-9134, 1987.

Raymond, C.: Shear margins in glaciers and ice sheets, J. Glaciol., 42, 90-102, 1996.

Reeh, N.: Parameterization of melt rate and surface temperature on the Greenland ice sheet, Polarforschung, 59, 113-128, 1989.

Rippin, D. M., Willis, I. C., Arnold, N. S., Hodson, A. J., and Brinkhaus, M.: Spatial and temporal variations in surface velocity and basal drag across the tongue of the polythermal glacier midre Lovenbreen, Svalbard, J. Glaciol., 51, 588-600, 2005.

Robinson, P. and Dowdeswell, J.: Submarine landforms and the behavior of a surging ice cap since the last glacial maximum: The open-marine setting of eastern Austfonna, Svalbard, Marine Geology, 286, 82-94, doi:10.1016/j.margeo.2011.06.004, 2011.

Rolstad, C., Chapuis, A., and Norland, R.: Electromagnetic interference in ground-based interferometric radar data from Kronebreen (Svalbard) calving front due to multipath scattering and tidal cycles, J. Glaciol., 55, 943-945, 2009.

Rott, H.: Advances in interferometric synthetic aperture radar (InSAR) in earth system science, Progress In Physical Geography, 33, 769-791, 2009.

Schoof, C.: Ice-sheet acceleration driven by melt supply variability, Nature, 468, 803-806, 2010.

Schuler, T., Loe, E., Taurisano, A., Eiken, T., Hagen, J., and Kohler, J.: Calibrating a surface mass-balance model for Austfonna ice cap, Svalbard, Ann. Glaciol., 46, 241-248, 2007.
Schytt, V.: Some comments on glacier surges in eastern Svalbard, Canadian Journal of Earth Sciences, 6, 867-871, 1969.

Sole, A. J., Mair, D. W. F., Nienow, P. W., Bartholomew, I. D., King, M. A., Burke, M. J., and Joughin, I.: Seasonal speedup of a Greenland marine-terminating outlet glacier forced by surface melt-induced changes in subglacial hydrology, J. Geophys. Res.earth Surface, 116, F03014, doi:10.1029/2010JF001948, 2011.

Solomon, S., Qin, D., Manning, M., Chen, Z., Marquis, M., Averyt, K., Tignor, M., and Miller, H.L. (Eds.): Climate Change 2007: The Physical Science Basis. Contribution of Working Group I to the Fourth Assessment Report of the Intergovernmental Panel on Climate Change, Cambridge University Press, Cambridge, United Kingdom and New York, NY, USA, available at: http://www.worldcat.org/isbn/0521705967, 2007.

Strozzi, T., Luckman, A., Murray, T., Wegmüller, U., and Werner, C. L.: Glacier motion estimation using SAR offset-tracking procedures, Ieee Transactions On Geoscience and Remote Sensing, 40, 2384-2391, 2002.

Sundal, A. V., Shepherd, A., Nienow, P., Hanna, E., Palmer, S., and Huybrechts, P.: Melt-induced speed-up of Greenland ice sheet offset by efficient subglacial drainage, Nature, 469, 521-524, 2011.

Svendsen, J. I. and Mangerud, J.: Holocene glacial and climatic variations on Spitsbergen, Svalbard, Holocene, 7, 45-57, 1997.

Thomas, R. H.: Force-perturbation analysis of recent thinning and acceleration of Jakobshavn Isbræ, Greenland, J. Glaciol., 50, 5766, 2004.

Tulaczyk, S., Kamb, W. B., and Engelhardt, H. F.: Basal mechanics of Ice Stream B, West Antarctica 1. Till mechanics, J. Geophys. Res.-Solid Earth, 105, 463-481, 2000.

van de Wal, R. S. W., Boot, W., van den Broeke, M. R., Smeets, C. J. P. P., Reijmer, C. H., Donker, J. J. A., and Oerlemans, J.: Large and rapid melt-induced velocity changes in the ablation zone of the Greenland Ice Sheet, Science, 321, 111-113, 2008.

van der Veen, C.: Tidewater calving, J. Glaciol., 42, 375-385, 1996.

Vasilenko, E., Navarro, F., Dunse, T., Eiken, T., and Hagen, J.: New low-frequency radio-echo soundings of Austfonna ice cap, Svalbard, in: The Dynamics and Mass Budget of Arctic Glaciers. Extended abstracts. Workshop and GLACIODYN (IPY) meeting, 16-19 February 2009, Kananaskis, Canada., edited by: Ahlstrøm, A. and Sharp, M., vol. 127 of Danmarks og Grønlands geologiske undersøkelse rappor, GEUS, Copenhagen: IASC Working Group on Arctic Glaciology, 2010.

Zwally, H. J., Abdalati, W., Herring, T., Larson, K., Saba, J., and Steffen, K.: Surface melt-induced acceleration of Greenland icesheet flow, Science, 297, 218-222, 2002. 